\title{
Wybrane wydarzenia z historii medycyny ze szczególnym uwzględnieniem raka
}

\author{
Część I
}

\section{Od chińskiego cesarza Huang Di i Imhotepa - lekarza faraona Dżesera (ok. 2700 p.n.e.) do Paracelsusa (1493-1541)}

\author{
Richard F. Mould
}

Niniejsze zestawienie chronologiczne stanowi wybór znaczących wydarzeń w historii medycyny bezpośrednio lub pośrednio związanych z chorobą nowotworową. Przyczynkiem do powstania tego opracowania był fakt, że ukazało się dotychczas stosunkowo niewiele zestawień chronologicznych dotyczących historii onkologii. Wśród tych, które zostały opublikowane, większość nie zawiera wykazów oryginalnych źródeł i nie przytacza lat życia lekarzy, chirurgów i badaczy. Autor ma zatem nadzieję, że poniższy uporządkowany w czasie i opatrzony bibliografią wybór wydarzeń i postaci będzie szczególnie pomocny dla wszystkich, którzy bardziej szczegółowo interesują się historią medycyny, a historią onkologii w szczególności.

\section{Annotated Biographical Bibliography with Special Reference to Cancer \\ Part 1 \\ From the Chinese Yellow Emperor Huang Ti \& the Egyptian Pharoah's Physician Imhotep (2700 BC) to Paracelsus (1493-1541) \\ This chronology is a selection of important events in the history of medicine which are directly or indirectly related to neoplastic disease. The reason underlying its compilation is that relatively few chronologies concerning oncology have previously been published and those that do exist do not always quote references or provide the dates of birth and death of the physicians, surgeons and scientists mentioned. It is hoped that this selected chronology will be of help to those writing in depth about the history of medicine and in particular about cancer.}

NOWOTWORY Journal of Oncology 2013; 63, 3: 257-262

Słowa kluczowe: rak, onkologia, chirurdzy, lekarze, farmacja, patologia, anatomia, anestezja, mikroskopia, epidemiologia, fizyka, chemia, nauki przyrodnicze, Huang Di, Imhotep, Yin i Yang, Hesi-Re, Georg Ebers, Edwin Smith, papirusy medyczne, Sushruta, Hipokrates, Aurelius Cornelius Celsus, Claudius Galen, Aetius z Amidy, Leonidas z Aleksandrii, Paweł z Eginy, Awicenna (Ibn Sina), Lanfranc z Mediolanu (Guido Lanfranchi), Teodoryk Borgognoni z Lukki, Peregryn Laziosi, Guy de Challiac, John z Alderne, Antonio Benivieni, Ambroise Paré, Gabriele Falloppio (Fallopius), Paracelsus (Phillippus Aureolus Theophrastus Bombastus von Hohenheim)

Key words: cancer, oncology, surgeons, physicians, pharmacy, pathology, anatomy, anaesthesia, microscopy, epidemiology, physics, chemistry, natural science, Huang Ti, Imhotep, Yin and Yang, Hesi-Ra, George Ebers, Edwin Smith, medical papyri, Sushruta, Hippocrates, Aurelius Cornelius Celsus, Claudius Galen, Aetius Amidenus, Leonides of Alexandria, Paul of Aegina, Avicenna (Ibn Sibā), Lanfranc of Milan (Guido Lanfranchi), Teodorico (Theodoric) Borgognoni, Peregrine Laziosi, Guy de Challiac, John of Alderne, Antonio Benivieni, Ambroise Paré, Gabriele Falloppio (Falloppius), Paracelsus (Philippus Aureolus Theophrastus Bombastus von Hohenheim) 


\section{Materiały źródłowe}

W literaturze na temat historii medycyny można znaleźć stosunkowo niewiele publikacji poświęconych historii raka, przywołujących wydarzenia (np. odkrycia, publikacje, zastosowanie nowych technik) bezpośrednio czy pośrednio związane z chorobą nowotworową. Ten fakt przyświecał autorowi przy sporządzaniu niniejszego przeglądu. Najnowsze obszerne monografie poświęcone historii medycyny to Oxford Handbook on the History of Medicine (2011) [1] oraz Companion Encyclopedia of the History of Medicine (1993) [2], jednak żadna z nich nie zawiera wielu informacji na temat raka. Co prawda, w roku 2000 Lee opublikował bardzo przydatną książeczkę zatytułowaną Dates in Oncology, jednak nie opatrzył jej bibliografią [3].

Bardzo dobre zestawienie istotnych wydarzeń w historii medycyny, ze szczególnym odniesieniem do raka, znajduje się w broszurce wydanej przez National Cancer Institute (U.S.) w 1998 roku pod tytułem Closing in on Cancer [4], jednak i tam nie zamieszczono piśmiennictwa. Jest także znacznie wcześniejsze wydawnictwo American Journal of Cancer Cushmana Haagensena (1933), gdzie szczegółowo opisano zawartość wystawy Graduate Fortnight on Tumors, zorganizowanej w New York Academy of Medicine w październiku 1932 roku. Przywołane tam źródła obejmują lata 1757-1932 [5]. Ponadto w 2008 roku w Nowotwory Journal of Oncology ukazał się artykuł pod tytułem Evolution of the knowledge of cancer from earliest times to the end of the $18^{\text {th }}$ century [6]. Książka z 1988 roku pióra Jamesa Olsona, historyka i jednocześnie pacjenta onkologicznego, The History of Cancer: An Annotated Bibliography, również zawiera wiele ciekawych i przydatnych informacji, lecz większość cytowanego piśmiennictwa powstała po roku 1945 [7].

Publikacja National Cancer Institute [4] wprowadza czytelnika w obszar zagadnień i materiałów w następujący sposób: „Ta broszura przedstawia przebieg splatających się historii nauki, medycyny i wiadomości o raku — od starożytnego Egiptu do chwili obecnej. Przez kilka tysięcy lat rak pojmowany był jedynie jako objaw zewnętrzny. Dopiero wynalezienie mikroskopu uwidoczniło samą tkankę i komórkę nowotworową. Skomplikowane biotechnologie rozwinięte w ostatnich dwóch dekadach umożliwiły naukowcom dążenie do wiedzy o mechanizmach na poziomie molekularnym, które wywołują niekontrolowany i śmiercionośny rozwój raka".

Oxford Handbook (...), wydany w październiku 2011 [1], to najnowsze wydawnictwo poświęcone historii medycyny. Redaktor Mark Jackson złożył hołd wcześniej wydanej książce Companion Encyclopedia (...) [2], a potrzebę wydania kolejnej publikacji uzasadnił „koniecznością uwzględnienia niezwykłego tempa, w jakim rozwinęła się historia medycyny w drugiej połowie XX wieku". Jednak podczas gdy Companion Encyclopedia (...) [2] zawierała rozdział zatytułowany "Rak", Handbook (...) [1] nie tylko nie zawiera osob- nego rozdziału na ten temat, ale też na 633 stronach tekstu znalazło się stosunkowo niewiele fragmentów w całości poświęconych nowotworom.

Handbook (...) zawiera 33 rozdziały podzielone na trzy części 1) Epoki, 2) Miejsca i Tradycje, 3) Zagadnienia i Metody. Zamieszczono tam przydatne ogólne źródła: Medycyna iZdrowie w Świecie Greków i Rzymian [132, 139, 160-166], Medycyna Średniowieczna [167-172] oraz Zdrowie i Medycyna w Epoce Oświecenia [173-177]. Trzy ogólne źródła odnoszące się do zagadnień raka zawierają The Dread Disease: Cancer and Modern American Culture Jamesa Pattersona z 1987 roku, Cancer Wars RN Proctora z roku 1996 oraz The Emperor of All Maladies: a Biography of Cancer Siddhartha Mukherjee z roku 2011 [28-30].

Rozdział pt. „Rak" z Companion Encyclopedia (...) [2] nie zawiera żadnych tabel chronologicznych, lecz tekst podzielony jest na części uporządkowane w czasie. Składa się z trzech działów: 1) Wprowadzenie i Historiografia, 2) Historia Medycyny Wewnętrznej (Pierwsze teorie humoralne; Anatomia patologiczna; Patologia komórek; Badania nad rakiem w XX wieku) oraz 3) Historia Medycyny Doświadczalnej (Instytucje; Terapie; Kancerogeny; Lęki i stereotypy).

Część materiału z Companion Encyclopedia (...) pokrywa się z tym, co już przywołaliśmy, ale część Historia Medycyny Doświadczalnej dostarcza nowych informacji, opisując znamienne sposoby, dzięki którym rak stał się społecznie i kulturowo zauważalny za sprawą licznych instytucji specjalistycznych ustanawianych od XIX wieku. Poszczególne hasła w Encyclopedii (...) nie były opatrzone bibliografią, zatem cytowaną literaturę autor odszukał w innych źródłach. W Companion Encyclopedia (...) znajdują się liczne, niezwykle użyteczne i istotne odnośniki [7, 31-44].

Trzeba jeszcze odnotować, że ani Handbook (...) [1], ani Companion Encyclopedia (...) [2] nie zawierają rozdziałów czy też części poświęconych chemioterapii w leczeniu nowotworów. Podstawowy podręcznik onkologii z roku 1970 autorstwa Laurena Ackermana i Juana del Regato [45] zawiera część zatytułowaną Chemotherapy of Cancer, w której przywołują pracę Heinricha Lissauera (1832-1908) z roku 1865. Lissauer relacjonował w niej zastosowanie pierwszego środka chemioterapeutycznego w leczeniu raka. Był nim arsenian potasu zastosowany w leczeniu białaczki [46].

\section{Kalendarium}

ok. 2700 p.n.e. Huang Di, legendarny Żółty Cesarz uważany za jednego z ojców chińskiej medycyny, napisał dzieło pod tytułem Nei Ching, najstarszy traktat o medycynie wewnętrznej. W znacznej części przyjmuje formę rozmowy cesarza z jego pierwszym ministrem na temat chorób i ich leczenia. Przedstawiono tam pierwszy opis guzów i wyłożono wiedzę na temat pięciu form leczenia: opieki duchowej, leczenia farmakologicznego, diety, akupunktury i leczenie schorzeń oddechowych [47]. 
- 2700-2600 p.n.e. Imhotep, niezwykle wszechstronny Egipcjanin, był kanclerzem i nadwornym lekarzem faraona Dżesera z III dynastii. Był też architektem i astrologiem. Zaprojektował piramidę schodkową w Sakkarze. Był też najwyższym kapłanem boga Ra w Heliopolis. Otaczano go kultem, a z czasem zaczęto uważać za syna boga Ptaha, i czczono jak boga. Zgodnie uważa się go za twórcę egipskiej medycyny i niekiedy przypisuje mu się autorstwo tzw. papirusu Smitha. Z tamtego okresu pochodzą opisy przypadków raka piersi. Egipcjanie stosowali wówczas leczenie przez wycięcie chorej tkanki [48].

ok. 2700 p.n.e. Yin i Yang. Chińskie podejście do zdrowia i choroby oparto na koncepcji dwóch pierwotnych przeciwstawnych zasad (sił): yin i yang. Yin to pierwiastek negatywny, związany z żeńską stroną natury. Yang oznacza aktywność i męski aspekt natury. Podobnie jak w przypadku hipokratejskich "humorów” (płynów), kluczowa dla stanu zdrowia miała być równowaga pomiędzy obydwoma elementami. Choroba rozwija się, gdy oddech, duch życia, który kieruje współzależnością między yin i yang, zostaje zablokowany. Celem akupunktury jest między innymi zapobieganie lub łagodzenie takich blokad przez nakłuwanie w określony sposób złotymi lub srebrnymi igłami $[49,50]$.

- ok. 2600 p.n.e. Nauki Imhotepa zostają skodyfikowane, sławę zyskuje też inny dostojny egipski lekarz i dentysta z czasów III dynastii - Hesi-Re.

- XVIII wiek p.n.e. W Babilonie powstaje Kodeks Hamurabiego. Zawarto w nim pierwsze prawa regulujące praktyki lekarskie i podniesiono kwestię odpowiedzialności i wynagrodzenia lekarzy.

ם ok. 1550 p.n.e. W tzw. Papirusie Ebersa opisano nowotwór piersi. Staroegipski papirus o tematyce medycznej został zakupiony na targu od arabskiego kupca przez niemieckiego egiptologa Georga Ebersa w 1873 i opublikowany w dwa lata później. Nie jest to księga czy traktat we właściwym znaczeniu, lecz raczej zbiór receptur i zaklęć. Można go uznać za prymitywną farmakopeę. Obejmuje on szeroką gamę przypadłości: od ugryzienia krokodyla po zapalenie odbytu. Pewne sformułowania odnoszą się zapewne do raka macicy lub szyjki macicy; guz opisany jako „zjadający macicę" i „zjadający wrzód” [51-53].

ok. 1500 p.n.e. - Papirus Smitha zakupiony przez Edwina Smitha w Tebach w 1862 roku. Staroegipski podręcznik chirurgiczny podnoszący kwestię najróżniejszych ran i złamań nie zawiera żadnych wzmianek o raku. Smith posługiwał się dokumentami sięgającymi roku 3000 p.n.e., a jego papirus jest najstarszym znanym traktatem chirurgicznym [54,55].

ok. $\mathbf{5 0 0}$ p.n.e. W starożytnych Indiach lekarz Sushruta (którego lata życia umieszczano w bardzo różnych okresach między VI w. p.n.e. aż do VI w. n.e.) w poświęconym chirurgii traktacie Sushruta Samhita opisał usuwanie guzów (pismo powstało na długo przed VIII wiekiem n.e.). Sushruta zszywał rany Inianymi nićmi i ścięgnami, używając do tego różnych igieł. Opisał też przyżeganie i inne metody tamowania krwawienia. Do znieczulenia używano napojów alkoholowych [56-58].

- V/IV w p.n.e. Hipokrates (460-370 p.n.e.) przekazywał swoim uczniom w szkole na wyspie Kos zasadę„Po pierwsze nie szkodzić" (Primum non nocere) i wierzył, że podstawowym obowiązkiem lekarza jest wnikliwa obserwacja pacjenta. Badał i opisał wiele różnych schorzeń, m.in. malarię, epilepsję, tężec, zapalenie płuc, błonicę i raka. To on nadał nazwę karkinos i karkinoma (grecka nazwa kraba) grupie chorób, które studiował, wśród których były raki piersi, macicy, żołądka i skóry. Twardy środek i przypominające szczypce kształty nacieków guzów przywodziły mu na myśl kraba. Hipokrates wierzył, że przyczyną powstawania raka jest nadmiar czarnej żółci [11, 59-62].

ok. 25 p.n.e. - 50 n.e. Aurelius Cornelius Celsus napisał dzieło De Medicina. Dzieło to zostało odnalezione dopiero w roku 1478 i wówczas światły papież Mikołaj V (skądinąd syn lekarza) zleciłjego publikację. Księga została podzielona na trzy części: dietetyczną , farmakologiczną i chirurgiczną. Celsus nie był lekarzem — był uczonym i gromadził informacje z różnych dziedzin (był swojego rodzaju encyklopedystą). Opisał pierwszą operację plastyczną z powodu raka. Posiadał szeroką wiedzę na temat historii naturalnej raka, jednak był przekonany, że jest to choroba w zasadzie nieuleczalna. Opowiadał się za chirurgicznym leczeniem mniej złośliwych form, na przykład usunięciem piersi czy wycinaniem raków warg czy twarzy [63-65].

79 n.e. Wybuch Wezuwiusza zniszczył Pompeje. Podczas prac archeologicznych znaleziono dom chirurga, a w nim wiele narzędzi chirurgicznych z brązu. Obecnie znajdują się one w muzeum w Neapolu. Wśród nich były: dwuklapkowy wziernik, nożyczki zaopatrzone w sprężynę, kleszcze, bańki (do stawiania) z brązu, typowy lancet, troakar z odpowiednim otworem dla umożliwienia odprowadzania płynu, mała łyżeczka (do wyskrobin?) z uchwytem z kości, wziernik i metalowa skrzynka na narzędzia chirurgiczne. Znaleziono również skaryfikator do puszczania krwi u koni. Wszystko wskazuje na to, że praktyka chirurga z Pompejów ograniczała się do stawiania baniek, puszczania krwi, leczenia urazów i jedynie niewielkich operacji [66].

ok. 130-200 n.e. Claudius Galen, rzymski lekarz, dzięki swoim dziełom stał się najbardziej wpływową postacią w medycynie aż do okresu odrodzenia. Na początku swojej kariery zdobywał wiedzę i umiejętności lecząc złamania i rozległe zranienia w szkole gladiatorów w Pergamonie. Był potem medykiem cesarza Marka Aureliusza. Napisał ok. 500 rozpraw, których treść nie była kwestionowana przez kolejnych 1500 lat. Usuwał guzy i zainfekowane kości oraz dokonywał resekcji żeber i mostków. Podobnie jak Hipokrates wierzył, że najlepiej jest "nie ruszać" raka. Galen twierdził, że rak może powstać na dwa sposoby: 1) strumień czarnej żółci przedostaje się do tkanki, której jedna postać może 
przerodzić się w raka, 2) strumień czarnej żółci, niezmieszany z krwią, natychmiast doprowadza do zachorowania na raka, najczęściej kobiecej piersi. Galen stosował termin atheroma do określenia guza powłok i był zwolennikiem chirurgicznego usuwania takich zmian. Sugerował też, że przyczyną zachorowania na raka piersi jest melancholia [16, 67-73].

- 400 n.e. Podczas wykopalisk archeologicznych natrafiono na starożytne czaszki noszące ślady leczenia guzów. W Dolnym Egipcie odnaleziono czaszkę mężczyzny w wieku 30-35 lat, który zapewne cierpiał z powodu guza części nosowej gardła lub zatoki szczękowej. Guz naciekał przez dół skrzydłowo-podniebny do zatoki szczękowej. W zewnętrznym przewodzie słuchowym znaleziono fragment Inianego płótna, które świadczy zapewne o podjętych próbach leczenia silnego bólu lub sączenia [74, 75].

n V/VI w. n.e. Aetius z Amidy jako pierwszy odnotował kliniczne oznaki raka piersi, takie jak wciągnięcie brodawek, przy okazji opisu prac Leonidasa, lekarza i chirurga praktykującego ok. 180 r. n.e. w Aleksandrii. Aetius był greckim lekarzem na dworze w Cesarstwie Bizantyjskim. Opowiadał się, podczas usuwania nowotworu, za ograniczeniem wycięcia do zmienionej chorobowo tkanki i za przyżeganiem rany w celu powstrzymania krwawienia [76].

- ok. 625-690 r. n.e. Paweł z Eginy, bizantyjski lekarz i chirurg, zasłynął jako autor dzieła Epitome medicae libri septum (Epitomes iatrikes biblio hepta). To kompendium wiedzy medycznej w siedmiu księgach zawierało m.in. opisy trepanacji, usunięcia migdałków, paracentezy i mastektomii. Chociaż pisma Pawła z Eginy w dużej mierze relacjonowały dokonania wcześniejszych autorów, to stanowią najpełniejsze przedstawienie stanu wiedzy zachodniego świata w VII wieku. Księgi zostały przetłumaczone w IX wieku na język arabski. Później w oryginalnej łacińskiej wersji wydano je w 1528 roku w Wenecji i w 1538 w Bazylei. Pierwszy angielski przekład miał miejsce w 1834 roku.

ש 750 r. n.e. W 1978 roku nieopodal miasta Arica w Chile znaleziono kobiecą mumię. Ustalono, że pochodzi ona z VIII wieku. Okazało się, że miała liczne przerzuty do kości, prawdopodobnie pierwotnym ogniskiem był rak piersi [77].

ש ok. 850 r. założono słynną medyczną szkołę w Salerno - pierwszą w Europie uczelnię kształcącą lekarzy.

- 980-1037 r. Awicenna (znany też jako lbn Sina) był perskim lekarzem, autorem naukowo-filozoficznej księgi Kitab-ash-shifa („Księga uzdrowienia”), stanowiącej swojego rodzaju encyklopedię, oraz traktatu o medycynie Al-Quanum Fil-Tibb (który w świecie łacińskojęzycznym znany był pod nazwą Canon Medicinae) składającego się z pięciu ksiąg. Dzieło Awicenny ma rangę niemal najsłynniejszej księgi w historii medycyny. Według uczonego medycyna teoretyczna (tibb nazari) oznacza zdobywanie wiedzy na temat zasad medycyny, czyli np. istnienia trzech rodzajów gorączki czy dziewięciu różnych temperamentów. Natomiast medycyna praktyczna (tibb amali) obejmuje metody postępowania, np. to, że powinno się podawać lekarstwo, które powstrzymuje rozwój zakażenia, następnie środek chłodzący, a po nim zmiękczający [78-80].

- XII w. w szkole medycznej w Salerno leczy się chorych na raka [81, 82].

- 1221 r. założono szkołę medyczną w Montpellier.

- 1296 r. Lanfranc z Mediolanu, znany też jako Guido Lanfranchi (1250-1306), był włoskim chirurgiem. Wplątał się w rozgrywki polityczne między Gibelinami i Gwelfami, po czym zbiegł przez Lyon do Paryża, gdzie został profesorem w Collège de St. Côme (Kolegium św. Kosmy). W roku 1296 napisał swoje wielkie dzieło pt. Ars completa totius chirurgiae. Księga zawierała części poświęcone anatomii, embriologii, wrzodom, przetokom, złamaniom, ziołom i farmacji oraz rakowi piersi. W Wenecji dzieło po raz pierwszy opublikowano w 1490 roku [83].

1267 r. Teodorico Borgognoni (1205-1296) z Lukki był jednym z najbardziej znaczących chirurgów w średniowieczu. W leczeniu raka opowiadał się za jak najwcześniejszą interwencją chirurgiczną, zanim guz będzie naciekał tkankę mięśniową i będzie zbyt unaczyniony. Zalecał wycinanie zmian z szerokim marginesem zdrowej tkanki. Borgognoni był dominikaninem; w 1240 roku został osobistym lekarzem papieża Innocentego IV. Praktykował medycynę obok obowiązków zakonnych. Niektóre źródła przypisują mu wprowadzenie podstawowych praktyk antyseptycznych w chirurgii. Przemywał rany przed zeszyciem aby ułatwić gojenie, a bandaże moczył uprzednio w winie, które stanowiło rodzaj środka dezynfekującego. W roku 1267 opublikował dzieło nazywane Cyrurgia lub Chirurgia, które obejmowało całą wiedzę o chirurgii, jaką dysponowano w średniowieczu [84].

- XIV w. Peregryn Laziosi (1265-1345) rzekomo osobiście doświadczył cudownego uleczenia raka po całonocnej modlitwie. Wstąpił do Zakonu Sług Najświętszej Maryi Panny, został kanonizowany w roku 1726 i stał się patronem chorych na raka [85].

- 1300 r. W XIV wieku w Kordobie praktykują liczni lekarze arabscy [86].

- 1363 r. Guy de Chaulliac (1300-1368), francuski chirurg określany niekiedy mianem „ojca chirurgii”. W roku 1363 ukazało się jego dzieło pt. Chirurgia Magna. Stanowiło podstawowy tekst na temat chirurgii aż do XVII wieku. W leczeniu raka de Chaulliac był zwolennikiem reżimu dietetycznego i przeczyszczania. Jeśli narośl wskazywała na możliwość powodzenia leczenia chirurgicznego, przeprowadzał operacje, sumiennie dbając o usunięcie całej chorej tkanki. Gdy w grę wchodziło jedynie leczenie paliatywne, stosował żrącą miksturę/pastę [87].

- XIV w. John z Alderne (1307-1390) był prawdopodobnie pierwszym znanym chirurgiem w Anglii. Prowadził praktykę w Londynie i wyczerpująco relacjonował swoje obserwacje m. in. opisał nowotwór złośliwy odbytu [88, 89]. 
- 1478 r. Odnaleziono De Medica Aureliusa Corneliusa Celsusa (ok. 25 p.n.e.-50 n.e.), a papież Mikołaj V zlecił jego publikację [63-65].

1507 r. Brat Antonia Benivieniego (ok. 1440-1502) z Florencji wydał po jego śmierci zebrane $w$ formie księgi opisy 20 sekcji zwłok. Była to pierwsza taka publikacja. Wydano ją pod tytułem De abditis nonullis ac mirandis morborum et sanationum causis. Chociaż głównym przyświecającym jej celem było badanie przyczyny śmierci, sprawozdania nie były szczególnie wnikliwe i często nie miały istotnego znaczenia. Jeden z opisów odnosi się w oczywisty sposób do raka żołądka (stomachum obcalluisse), jednak Benivieni tego nie rozpoznał [90].

1518 r. The Royal College of Physicians otrzymał Statut od króla Henryka VIII.

1575 r. Ambroise Paré (1510-1590) był samoukiem i zaczynał jako cyrulik, a został najwybitniejszym chirurgiem i autorem prac na temat chirurgii w dobie renesansu. $\mathrm{Na}$ polach bitew ocalił tysiące istnień, zaprzestając używania wrzącego oleju do czyszczenia ran. Zaniechał przyżegania i nauczał podwiązywania naczyń podczas amputacji. Paré zalecał chirurgiczne leczenie raka tylko wówczas, gdy możliwe było jego całkowite usunięcie [91-95].

1584 r. Gabriele Falloppio (1523-1562), chirurg włoskiego renesansu i jeden z najwybitniejszych badaczy ludzkiej anatomii, znany też pod łacińskim imieniem Fallopius. Studiował w Ferrarze, a później wykładał w Pizie i w Padwie. W swoich pismach obszernie wypowiadał się m.in. na temat raka.W leczeniu stronił od chirurgicznych rozwiązań, polegał natomiast na działaniu różnych past ze żrących substancji. Jego ulubiona mikstura składała się przede wszystkim z arszeniku. W wydanym pośmiertnie Opera genuina omnia opisał wiele różnych rodzajów guzów [96].

घVI w. Paracelsus, czyli Philippus Aureolus Theophrastus Bombastus von Hohenheim (1493-1541), spaliłw 1527 roku dzieła Galena i Awicenny, symbolicznie zrywając z przeszłością. Paracelsus odrzucił pogląd, że choroba wywoływana jest przez zachwianie równowagi humorów w ciele. Zamiast tego twierdził, że rak powstaje na skutek nadmiaru lub niedoboru określonych substancji (był pionierem jatrochemii) ale nie bez elementów o charakterze mistycznym [97-102].

\section{Richard F. Mould MSc, PhD}

4, Town End Meadow

Cartmel

Grange-over-Sands

Cumbria LA11 6QG

United Kingdom

e-mail: manorroadsouthport@yahoo.co.uk

\section{Piśmiennictwo}

1. Jackson M (red.) The Oxford Handbook of the History of Medicine. Oxford: Oxford University Press, 2011, 672 stron.

2. Bynum WF, Porter R, (red.) Companion Encyclopedia of the History of Medicine. New York: Routledge, 1993, tom 1, s. 1-778, tom 2, s. 783-1806. Także: Cantor D. Cancer, rozdz. 25, s. 537-561.
3. Lee HSJ, (red.) Dates in Oncology. Landmarks in Medicine Series. New York: Parthenon, 2000, 124 stron.

4. National Cancer Institute. Closing in on Cancer: Solving a 5,000 Year-Old Mystery. National Institutes of Health Publication No. 98-2955, 1998, 54 strony.

5. Haagensen CD. An exhibit of important books, papers, and memorabilia illustrating the evolution of the knowledge of cancer. For the Graduate Fortnight on Tumors at the New York Academy of Medicine, 17-28 October 1932. Am J Cancer 1933; 18: 42-126.

6. Mould RF. Evolution of the knowledge of cancer from earliest times to the end of the $18^{\text {th }}$ century. Nowotwory J Oncol 2008; 58: 103e-115e.

7. Olson JS. The History of Cancer: an Annotated Bibliography. New York: Greenwood Press, 1989.

8. Jackson R. Doctors and Diseases in the Roman Empire. London: British Museum, 1988

9. Grmek MD. Diseases in the Ancient Greek World. Baltimore: Johns Hopkins University Press, 1989.

10. Van der Eijk PJ, Horstmanshoff HFJ, Schrijvers PH, (red.) Ancient Medicine in its Socio-Cultural Context. Amsterdam/Atlanta: Rodopi, 1995.

11. Jouanna J. Hippocrates. Baltimore: Johns Hopkins University Press, 1999

12. Lloyd GER. In the Grip of Disease. Oxford: Oxford University Press, 2003.

13. Nutton V. Ancient Medicine. London: Routledge, 2004.

14. Van der Eijk PJ.Medicine and Philosophy in Classical Antiquity. Cambridge: Cambridge University Press, 2005.

15. Langslow DR. Medical Latin in the Roman Empire. Oxford: Oxford University Press, 2006.

16. Hankinson RJ. The Cambridge Companion to Galen. Cambridge: Cambridge University Press, 2008.

17. Siraisi N. Medieval and Renaissance Medicine. Chicago: University of Chicago Press, 1990.

18. Rawcliffe C. Medicine and Society in Later Medieval England. Stroud: Alan Sutton, 1995.

19. Grmek MD, red. Western Medical Thought from Antiquity to the Middle Ages. Cambridge MA: Harvard University Press, 1998.

20. Olsen LT. Charms and prayers in medieval medical theory and practice. Social History of Medicine 2003; 16: 343-366.

21. Bjork RE, ed. The Oxford Dictionary of the Middle Ages. tom 1-4, Medicine. Oxford: Oxford University Press, 2010.

22. Wallis F, (red.) Medieval Medicine: a Reader. Toronto: University of Toronto Press, 2010.

23. Cunningham A, French $\mathrm{R}$, (red.) The Medical Enlightenment of the $18^{\text {th }}$ Century. Cambridge: Cambridge University Press, 1990.

24. Lindemann M. Health and Healing in $18^{\text {th }}$ Century Germany. Baltimore: Johns Hopkins University Press, 1996.

25. Brockliss L, Jones C. The Medical World of Early Modern France. Oxford: Clarendon Press, 1997.

26. Gentilcore D. Healers and Healing in Early Modern Italy. Manchester: Manchester University Press, 1998.

27. Elmer P. The Healing Arts: Health, Disease and Society in Europe, 1500-1800. Manchester: Manchester University Press, 2004.

28. Patterson JT. The Dread Disease: Cancer and Modern American Culture. Cambridge MA: Harvard University Press, 1987.

29. Proctor RN. Cancer Wars: How Politics Shapes What We Know and Don't Know About Cancer. New York: Basic Books, 1996.

30. Mukherjee S. The Emperor of All Maladies: a Biography of Cancer. London: Fourth Estate, 2011.

31. Sigerist HE. The historical development of the pathology and therapy of cancer. Bull New York Academy of Medicine 1932; 8: 642-653.

32. Strickland S. Politics, Science and Dread Disease: a Short History of United States Medical Research Policy. Cambridge MA: Harvard University Press, 1972.

33. YarmachuckWA. The origins of the National Cancer Institute. J National Cancer Institute 1977; 59 (suplement): 551-558.

34. Rettig RA. Cancer Crusade. The Story of the National Cancer Act of 1971. Princeton: Princeton University Press, 1977.

35. Shimkin MB. Contrary to Nature. Washington DC: National Institutes of Health, 1977.

36. Rather LJ. The Genesis of Cancer. A Study in the History of Ideas. Baltimore: Johns Hopkins University Press, 1978.

37. Bud RF. Strategy in American cancer research after World War II: a case study. Social Studies of Science 1978; 8: 425-459.

38. Panem S. The Interferon Crusade. Washington DC: Brookings Institute, 1984.

39. Ross WA. The Official History of the American Cancer Society. New York: Arbor House, 1987. 
40. Jacyna S. The laboratory and the clinic: the impact of pathology on surgical diagnosis in the Glasgow Western Infirmary, 1875-1910. Bull History of Medicine 1988; 62: 384-406.

41. Austoker J. A History of the Imperial Cancer Research Fund 1902-1986. Oxford: Oxford University Press, 1988.

42. Austoker J, Bryder L, (red). Historical Perspectives on the Role of the MRC. Essays in the History of the Medical Research Council of the United Kingdom and its Predecessor, the Medical research Committee, 1913-1953. Oxford: Oxford University Press, 1989.

43. Richards E. Vitamin C and Cancer: Medicine or Politics? London: MacmilIan, 1991.

44. Pinell Patrice. Naissance d'un Fléau. Histoire de la Luttre Contre le Cancer en France (1840-1940). Paris: Editions Métaillié, 1992.

45. Ackerman LV, del Regato JA. Cancer Diagnosis, Treatment and Prognosis. 4 wyd., St. Louis: CV Mosby, 1970, s. 28-30.

46. Lissauer H. Zwei fälle von leucaemie. Berliner klinische Wochenschrift 1865; 2: 403-404.

47. LoV, Stanley-Baker M. Chinese medicine. W: Jackson M, red. The Oxford Handbook of the History of Medicine. Oxford: Oxford University Press, 2011, s. 150-156.

48. Boulos FS. Oncology in Egyptian papyri. W: Retsas S, red. Paleo-oncology: the Antiquity of Cancer. 5 wyd. London: Farrand Press, 1986.

49. Gairdner D. The fate of the foreskin: a study of circumcision. \{lncludes illustrations of wall paintings showing circumcision, births of royal children and surgical instruments, in the tomb of Ptah-Hotep, a physician who died in 2340BC and was buried in Saqqara\} Br Med J 1949; 2: 1433-1437.

50. Dixon B. Beyond the Magic Bullet. London: George Allen \& Unwin, 1978.

51. Bryan CP. The Papyrus Ebers (Translation from the German Version) London: Geoffrey Bles, 1930.

52. Ebbell B. The Papyrus Ebers: the Greatest Egyptian Medical Document. Copenhagen: Levin \& Munksgaard, 1937.

53. Butterfield WC. Tumour treatment 3000 BC. Surgery 1966; 60:476-479.

54. Breasted JH. The Edwin Smith Papyrus. Chicago: University of Chicago Press, 1930.

55. Abdel-Kader H. Life in Ancient Egypt. 2 wyd. Cairo: Al Ahram Commercial Press, 1982.

56. Kavirai Kunja Lal Bhishagratna. Sushruta: an English Translation of the 'Sushruta Samhita', based on the Original Sanskrit Text. Calcutta: Wilkins Press, 1907.

57. Veith I. The surgical achievements of ancient India: Sushruta. Surgery 1961; 41: 564-568.

58. Suraiya JN. Medicine in ancient India with special reference to cancer. Am J Cancer 1973; 10: 391-402.

59. Littré E. Oeuvres Complètes d'Hippocrate. 10 volumes. Paris: Baillière, 1839-1861.

60. Lund FB. Hippocratic surgery. Annals Surgery 1935; 102: 531-547.

61. Glaser S. Hippocrates and proctology. Proc Roy Soc Med 1969; 62: 380-381.

62. Barrow MV. Portraits of Hippocrates. Med History 1972; 16: 85-88.

63. Aurelius Cornelius Celsus. De Re Medica.LibriOcto ... cum Adnotationibus \& Correctionibus R. Constanti. Lugduni, apnd Guliel. Rouillium, 1566.

64. Zeiss E. Die Literatur und Geschichte der plastichen Chirurgie. Leipzig: Wilhelm Englemann, 1863, s. 187.

65. Castiglioni A. Aurelius Cornelius Celsus as a historian of medicine. Bull History Medicine 1940; 8: 857-873.

66. Senn N. Pompeiian surgery and surgical instruments. Med News 1895; 67: 701-708.

67. Galen. Opera Omnium ... Josepho Tectandro Cracoviensi interprete. Basileae, apud And. Cratandrum, 1536.

68. Kühn CG. Claudii Galeni Opera Omnia. 22 tomy. Leipzig, 1821-1833.

69. Galen C. Methodus Medendi, with a Brief Declaration of the Worthie Art of Medicine, the Office of a Chirgion, and an Epitome of the Third Booke of Galen, of Naturall Faculties. T Gale, trans. London:Thomas East, 1586.

70. Rather LJ. Disturbance of function (functio laesa): the legendary fifth sign of inflammation, added by Galen to the four cardinal signs of Celsus. Bull New York Acad Med 1971; 47: 303-322.

71. Toledo-Pereryva LH. Galen's contribution to surgery. J History Medicine \& Allied Sciences 1973; 28: 357-375.
72. Reedy J. Galen on cancer and related diseases. Clio Medica 1975; 10: 227-238.

73. Lytton DG, Resuhr LM. Galen on abnormal swellings. J History Medicine \& Allied Sciences 1978; 33: 531-549.

74. El-Rakhawy MT, El-Eishi HI, El-Nofely A, Gaballah MF. A contribution to the pathology of ancient Egyptian skulls. Anthropologie (Brno) 1971; 9: 71-78.

75. Strouhal E. Ancient Egyptian case of carcinoma. Bull New YorkAcad Med 1978; 54: 290-302.

76. Leonides of Alexandria. Graeci contractae ex Veteribus Medicinae Tetrabiblos ... Basileae, impensis Hier. Frobenii \& Nic. Episcopii, 1542,

77. Allison MJ et al. Metastatic tumor of bone in a Tiahuanaco female. Bull New York Acad Med 1980; 56: 581-587.

78. Ibn Sinā, Qänum dar Tebb (Canon of medicine), Persian translation, tom 1:3-4; Mohammad-Hosein 'Aqili Kholāsat al-hekmat [Digest of Medicine], lithograph edn, Bombay, [1261] 1845, 2

79. Wickens GM. Avicenna: scientist and philosopher. London: Luzac \& Co. 1952.

80. Eltorai I. Avicenna's view on cancer from his canon. Am J Chinese Med 1979; 7: 276-284

81. Corner GW. Salernitan surgery in the $12^{\text {th }}$ century. Br J Surgery $1937 ; 25$ : 84-99.

82. Reichborn-Kjennerud I.The School of Salerno and surgery in the north during the saga era. Tjomsland A (tłumacz.). Ann Med Hist 1937; 9: 321-327.

83. Lanfranc. Practica quae dicitur Ars complete totius Chirurgiae [Chirurgia Magna]. Venice, 1490

84. Campbell E, Colton J. The Surgery of Theodoric. New York: Appleton Century Crofts, 1955.

85. Jackson R. St. Peregrine OSM, Patron Saint of cancer patients. Can Med Assoc J 1971; 111: 824-827.

86. Zimmermann LM, Veith I. Great Ideas in the History of Surgery. Baltimore: Williams \& Wilkins, 1961.

87. Guy de Chauliac. Chyrurgia ... Addita recepta aque balnei de porecta ... (Lyons), Vincentius de Portonariis de Tridino de Monteferrato, c.1510. \{Chirurgia Magna Guy de Chauliac'a była najważniejszym tekstem chirurgicznym XIV i XV wieku\}

88. Millar TM. John of Alderne, the father of British proctology. Proc Royal Soc Med 1954; 47: 75-84.

89. Swain CP. A $14^{\text {th }}$ century description of rectal cancer. World J Surgery 1983; 7: 304-307.

90. Antonio Benivieni. De Abditis nonnullis ae Mirandis Morborum et Sanationum Causis. Florentiae, impensa Phillipi Giuntae, 1507.

91. Ambroise Paré. Les Oeuvres de M. Ambroise Paré ... Paris: Gabriel Buon 1575.

92. Hamby W, ed. The Case Reports and Autopsy Records of Ambroise Paré. Springfield: Charles C Thomas, 1960. (Translated from: Malgaigne JP. Oeuvres Completes d'Ambroise Paré. Paris, 1840)

93. Paré A. Ten books of surgery with the magazine of the instruments necessary for it. Linker RW, Womack N, (tłumacz.). Athens: University of Georgia Press, 1969

94. Boyd HH. Ambroise Paré: sawbones or scientist? J History Medicine \& Allied Sciences 1960; 15: 268-281.

95. Hamby WB. The Case Reports and Autopsy Records of Ambroise Paré Springfield: Charles C Thomas, 1960.

96. Gabriele Falloppius. Opera quae adhne extant omnia ... Francofurti, apud Haeredes Andreae Wecheli, 1584.

97. Pagel W. Paracelsus: Introduction to Philosophical Medicine in the Era of the Renaissance. Basle: Karger, 1958.

98. Pagel W. Van Helmont's concept of disease: to be or not to be? The influence of Paracelsus. Bulletin History of Medicine 1972; 46: 419-454.

99. Pagel W. Joane Baptista van Helmont. Reformer of Science and Medicine. Cambridge: Cambridge University Press, 1982.

100. Grell OP, ed. Paracelsus: the Man and his Reputation, his Ideas and Their Transformation. Leiden: Brill, 1998.

101. Webster C. Paracelsus: Medicine, Magic and Mission at the End of Time. New Haven: Yale University Press, 2008.

102. Grabman JP. Theophrastus Paracelsus. J History of Medicine \& Allied Sciences 1974; 29: 228-229. 